\title{
Board Composition And Firm Performance: Evidence From Nigeria
}

\author{
Angela Ifeanyi Ukemenam \\ Department of Banking and Finance, University of Nigeria, Enugu Campus \\ angela.ukemenam@unn.edu.ng
}

Ifeoma Betty Ezike

Monetary Policy Department, Central Bank of Nigeria

bettyezike@yahoo.com

\section{Ikenna Franklin Chijioke}

Niger Delta Development Commission, Owerri, Imo State, Nigeria. ikedivine@yahoo.com

\begin{abstract}
This study examines the effect of board composition on firm performance, using annualized data from 1998 to 2017. The study adopted the Tobin's Q as measure of performance and ratio of nonexecutive directors to total board size as measure of board composition. Firm size and firm age were introduced as controlled variables. The study employed the static panel model. The evidence suggests that the estimated coefficients of board composition have statistically negative effect on firm performance. The findings suggest that non-executive dominated board do not translate to effective monitoring in Nigeria.
\end{abstract}

Keywords: Board Composition, Firm Performance, Nigeria, Firm Age, Firm Size

\section{Introduction}

The last two decades have witnessed unprecedented corporate failure due to scandals across the globe. The scandals evinced serious public interest on the role of the board, and the consciousness of how to make corporate boards effective. Most countries responded to this by introducing corporate governance codes. Banks were brought to the fore, because of the domino effect of bank failure in an economy. The Nigerian Securities and Exchange Commission responded to the global trend by introducing corporate governance codes for all quoted companies in Nigeria. Similarly, the Central Bank of Nigeria, in keeping with their mandates of promoting good corporate governance in Nigeria and also complying with the global trend, introduced the Code of Corporate Governance for Banks in Post Consolidation, 2006, which was revised in 2011, but yet to be approved, though the exposure draft is in the public domain. Some of the common 
recommendations of the Code of Corporate Governance for Banks in Post Consolidation that were sustained in the latest revision are; the separation of the position of the CEO and the board chair; the dominance of non-executive directors, ten years tenure for the CEO, twelve years tenure for non-executive board members; among others.

These recommendations are geared towards resolving the principal-agency problem and reducing agency cost associated with the separation of ownership from management. Agency theory is anchored on separation between agents (managers) and owners (shareholders). The theory argues that since agents are not the direct owners, they are likely to pursue personal gains to the detriment of the shareholders (Jensen and Meckling, 1976). This arrangement creates serious agency costs. Most importantly, the individual shareholders do not have the incentive to monitor the agents because of information asymmetry and huge monitoring costs. Thus, board governance arrangement focuses on the effective monitoring of the agents (management) against self-serving bahaviour, in order to protect the interest of the shareholders.

This is premised on the common notion that management possesses important knowledge of firm activities, which are very expensive for the owners to acquire, and such information asymmetry becomes disincentive for owners to individually monitor management. Thus, most corporate governance models advocate for a non-executive dominated board as a mechanism for ensuring effective monitoring and board impendence. The role of the board is more important in emerging markets and developing economies, because of weakness of other governance mechanisms like financial markets, weak regulatory environment and institutions. While resolving the principalagent problem is an important issue in the corporate governance of banks, the global financial crisis has exposed other forms of weaknesses in banks' corporate governance systems. Sanusi (2010) argue that "some boards lacked independence; and directors often failed to make meaningful contributions to safeguard the growth and development of the banks." This raises an important question of whether the sufficient or insufficient representation of non-executive directors is the possible explanation for boards' failure to fulfill their monitoring role in the banking industry.

This article strives to provide answers to the question by investigating the link between board composition and firm performance using data from Nigeria. The motivation for this study is two folds. First, the subject of corporate governance from empirical standpoint has suffered neglect both in the academia and public policy in Nigeria. The relative neglect of corporate governance in Nigerian public policy is perhaps a reflection of the paucity of empirical works in this area. Also, the Code of Corporate Governance for quoted firms in Nigeria and Central Bank of Nigeria's Code of Corporate Governance for Banks and other Financial Institutions (2006), view board composition from the prison of effective monitoring. Secondly, the article will provide a better insight on accurate monitoring mechanisms that resolves a potential conflict of interest between management and shareholders. To achieve these, the study begins with a review of related literature. The next section discusses the research methodology; followed by discussion of important results /findings; while the last section concludes the paper.

\section{Review of Related Literature}

Generally, the board or top management of any firm is composed of executive and non-executive directors - its principal owners and hired-managers from outside of its principal owners. Recent theoretical and empirical literature on ownership configuration and management emphasizes the stability of employee ownership. Dow (2003) used "incentive optimism vs. finance pessimism" to 
capture the relative advantage of employee ownership. Incentive optimism argues in favour of aligning the incentives of insiders with bank performance, while finance pessimism argues that for the sake of risk diversification, management is better delegated to risk neutral investors. Despite this controversy in governance literature, most corporate governance codes overwhelmingly favour board dominated by non-executive directors.

The logic behind this line of thinking is based on a stable business model. It is argued that insiders would have strong incentive to be owners. The alignment of control with ownership becomes more apparent in volatile corporate environments, such as emerging and developing economies like Nigeria, where the likelihood of losing one's job is higher. Thus, managerial ownership is expected to provide implicit or explicit insurance or control mechanism that reduces the probability of job loss by insiders in order to protect investment in human capital. The insurance or control mechanism is more relevant to firms owned by management because of their huge stake or associated loss as result of been fired.

Agency theorist, however, perceive corporate governance as a major predictor of firm performance and higher stock prices. They argued that managers perform better when they are better supervised and that effective supervision will automatically reduce agency cost and improve firm performance, irrespective of ownership. The disagreement between opponents and proponents of agency theory also reflects in empirical results, as study that relied on agency theory in investigating the link between cooperate governance and firm performance report mixed results. Raheja (2005) found that firms dominated by non-executive directors perform better than firm dominated by executive directors. Also, Forsberg, (2009), found positive relationship between the proportion of outsiders and the role of auditors. Fich and Shivdasani (2006) found no such relationship between the composition of the board and firm value.

At the fifth annual conference of the Chartered Institute of Bankers of Nigeria (CIBN) in 2011, Jaiyeola observed that the issue of corporate governance has gone beyond balance sheet and liquidity but now on the issue of 'Trust' because there is need to rebuild trust and confidence in the Nigerian corporate environment. Apart from the issue of rebuilding trust and confidence in the, the issue of board size and composition is very strategic to effective performance of firms. That is why Pfeffer (1972), Zahra and Pearce (1989) argued that bigger board can use collective strength of its members to resist irrational decisions of chief executive officers, while Yermack (1996; and 2006) believes that small boards engender greater efficiency in decision-making coupled with less agency costs. Jensen and Meckling (1976) used the term 'Agency cost' to describe reduction in the value of the firm arising from the behaviour where the hired managers tend to maximise the value of their own utility rather than that of the firm. Despite the plethora of theoretical and empirical literature on the relationship between board composition and the financial performance of firms, little is known about the case of Nigeria. For instance, the bulk of the studies were conducted in Europe and advance economies. Few studies from emerging markets concentrated on South Africa, Brazil, India, Mexico and China. This study intends to fill the gap in literature by investigating the Nigerian case. 


\section{Data and Methodology}

\subsection{Data}

The data were handpicked from the annual reports and statement of account of quoted companies in Nigeria for the end-period 1998-2017. All companies whether distressed, merged and/or still existing, for whose annual report existed for at least five years were included in the sample. The decision to use 1998 was influenced by the fact that the Company and Allied Matters Act 1990 as amended was the first company law in Nigeria to make strong prescription for board composition (executive and non-executive representation on corporate board). Thus, we expect that such recommendation will have at least, 8 years lag effect.

The data for the study comprised of dependent, independent and controlled variables. The dependent variables are measures of corporate performance. Though there have been serious controversies regarding what constitutes corporate performance (Cochran and Wood, 1984; Ittner and Larcker, 2003). For the purpose of the study, we adopted Tobin $Q$ as proxies for firm

performance. Tobin's $\mathrm{Q}$ is defined as ratio of total assets minus book value of equity plus market value of equity to book value of total assets. A total of 161 firms were selected representing 3220 observations. The independent variable is board composition proxied by total number of nonexecutive directors divided by total board size. The study also controlled for other variables that could impact on corporate performance. Specifically, firm size proxied as log of total assets, and bank age proxied as log of years from date of incorporation entered the equation as controlled variables.

\subsection{Empirical Technique}

We investigate the linkage between board composition and firm performance using the Generalised method of moments (GMM) dynamic model with unbalanced panel data (Arellano and Bond, 1991; and Blundell and Bond, 1998). The use of panel data enables us to investigate the relations between board composition, as well as controlling for the unobserved heterogeneity of the 116 selected firms in Nigeria. We state the general framework for a static panel study as:

$$
Y_{i t}=\alpha_{i}+\beta X_{i t}+\mu_{i t} \ldots \ldots \ldots \ldots \ldots \ldots \text { (1) }
$$

Where: $Y_{i t}$ is the dependent variable and $X_{i t}$ is a vector representing the explanatory variables. The cross-sectional and time series dimensions are represented respectively by $i$ and $t$ subscripts. The composite error term can be decomposed into specific effects and the remainder disturbance term. Hereafter $i$ referred to individual the individual firms. To capture the individual country specific effects, we decompose $\mu_{i t}$ by re-writing equation 1 as follows:

$$
Y_{i t}=\alpha_{i}+\beta X_{i t}+\eta_{i}+\lambda_{t}+\varepsilon_{i t} \ldots \ldots \ldots \ldots \ldots \ldots \ldots \ldots \text { (2) }
$$

Where Yit is defined as the measures of firm performance (ROA); Xit is a vector of independent variables. $\eta_{i}$ is the firm specific effects; $\lambda_{t}$ is the time specific effect; and $\varepsilon$ it is the disturbance term that captures the effects of the omitted variables. 


\section{Results}

In this section, the respective results were presented and discussed. Tables $1-3$ present the empirical results. Table 1 presents the Random-Effects result that uses Tobin's $Q$ as a measure of performance. The evidence from the results shows that board composition has significant negative impact on performance. The controlled variables displayed mixed results. For instance, firm age is a major predictor of firm performance as the impact is positive and significant while firm size is a negative predictor of firm performance. The results show that rho (variance not explained by differences across firms) has a positive coefficient of 0.00 in the observation. Since the $t$-values test the hypothesis that each coefficient is different from zero, the result of $t$-value shows that the model is consistent with the dataset. The F-value affirms the result of the $\mathrm{t}$-value.

Table 1: Random-Effect Panel Regression Result (Tobin's Q)

\begin{tabular}{|c|c|c|c|c|}
\hline Variable & Coefficient & Std. Error & t-Statistic & Prob. \\
\hline$C$ & 0.103072 & 0.000799 & 129.0300 & 0.0000 \\
\hline LOGTA & -0.008163 & 0.000138 & -59.05109 & 0.0000 \\
\hline LOGAGE & 0.037386 & 0.000791 & 47.23604 & 0.0000 \\
\hline Board composition & -0.104737 & 0.000695 & -150.7500 & 0.0000 \\
\hline \multicolumn{5}{|c|}{ Effects Specification } \\
\hline & & & S.D. & Rho \\
\hline Cross-section random & & & 0.000000 & 0.0000 \\
\hline Idiosyncratic random & & & 0.004428 & 1.0000 \\
\hline \multicolumn{5}{|c|}{ Weighted Statistics } \\
\hline R-squared & 0.903220 & Mean dependent var & & 0.092930 \\
\hline Adjusted R-squared & 0.903130 & S.D. dependent var & & 0.013867 \\
\hline S.E. of regression & 0.004316 & Sum squared resid & & 0.059910 \\
\hline F-statistic & 10004.65 & Durbin-Watson stat & & 1.844579 \\
\hline Prob(F-statistic) & 0.000000 & & & \\
\hline \multicolumn{5}{|c|}{ Unweighted Statistics } \\
\hline R-squared & 0.903220 & Mean dependent var & & 0.092930 \\
\hline Sum squared resid & 0.059910 & Durbin-Watson stat & & 1.844579 \\
\hline
\end{tabular}

Table 2 presents the fixed effect panel results. The result also revealed that board composition is a negative predictor of firm performance and the coefficients are statistically significant. While the coefficient of firm size is positive and statistically significant, the coefficient of firm age is negative and statistically significant. The finding is not consistent with the random-effect results in table 1. Two-tail p-value test is found to be higher than 0.05 at $95 \%$, which shows that the time invariant variables have significant influence on the dependent variable. Adjusted R-Square shows the same as R-Square but adjusted by the number of variables. The result shows that the number of variable 
is small and number of cases is very large, then adjusted R-Square is closer to R-Square. This provides a more honest association between the dependent and independent variables.

Table 2: Fixed Effect Panel Regression Results (Tobin's Q)

\begin{tabular}{|c|c|c|c|c|}
\hline Variable & Coefficient & Std. Error & t-Statistic & Prob. \\
\hline C & 0.103072 & 0.000799 & 129.0300 & 0.0000 \\
\hline LOGTA & -0.008163 & 0.000138 & -59.05109 & 0.0000 \\
\hline LOGAGE & 0.037386 & 0.000791 & 47.23604 & 0.0000 \\
\hline Board Composition & -0.104737 & 0.000695 & -150.7500 & 0.0000 \\
\hline \multicolumn{5}{|c|}{ Effects Specification } \\
\hline \multicolumn{5}{|c|}{ Cross-section fixed (dummy variables) } \\
\hline R-squared & 0.903220 & Mean dependent var & & 0.092930 \\
\hline Adjusted R-squared & 0.898058 & S.D. dependent var & & 0.013867 \\
\hline S.E. of regression & 0.004428 & Akaike info criterion & & -7.952311 \\
\hline Sum squared resid & 0.059910 & Schwarz criterion & & -7.642792 \\
\hline Log likelihood & 12967.22 & Hannan-Quinn criter. & & -7.841378 \\
\hline F-statistic & 174.9736 & Durbin-Watson stat & & 1.844579 \\
\hline Prob(F-statistic) & 0.000000 & & & \\
\hline
\end{tabular}

The results from random and fixed effects show that both models are consistent with the dataset. However, to choose the more consistent model with the dataset, we use the Hausman test. The Hausman test is aimed at identifying the most optimal results between fixed effects and random effects regressions, or which is statistically more consistent with the dataset used in the study, as well as the objectives of the study. The test is necessary because of the contradictory or mixed results from the fixed-effects and random-effects regression. Results of the test are reported in table 3 , and showed some significant support for the fixed effects regression than the random effects. The p-value was highly significant at $5 \%$ level. The null hypothesis of an equality of fixed and random effects regression estimations was rejected. The result provided evidence on lack of random effects in the model; and that the model for fixed effects regression captures both the group and time effects.

Table 3: Hausman Test (Tobin's Q)

\begin{tabular}{lccr}
\hline \hline Test Summary & Chi-Sq. Statistic & Chi-Sq. d.f. & Prob. \\
\hline \hline Cross-section random & 0.000000 & 3 & 1.0000 \\
\hline \hline
\end{tabular}

* Cross-section test variance is invalid. Hausman statistic set to zero.

** WARNING: estimated cross-section random effects variance is zero.

Cross-section random effects test comparisons:
Variable
Fixed
Random
Var(Diff.)
Prob. 


\begin{tabular}{crrrr}
\hline \hline LOGTA & -0.008163 & -0.008163 & 0.000000 & 0.0000 \\
LOGAGE & 0.037386 & 0.037386 & 0.000000 & 1.0000 \\
Board Composition & -0.104737 & -0.104737 & 0.000000 & 1.0000 \\
\hline \hline
\end{tabular}

Cross-section random effects test equation:

Dependent Variable: TOBINS_Q

Method: Panel Least Squares

Date: 06/13/14 Time: 11:50

Sample: 19932012

Periods included: 20

Cross-sections included: 161

Total panel (balanced) observations: 3220

\begin{tabular}{crrrr}
\hline \hline Variable & Coefficient & Std. Error & t-Statistic & Prob. \\
\hline \hline C & 0.103072 & 0.000799 & 129.0300 & 0.0000 \\
LOGTA & -0.008163 & 0.000138 & -59.05109 & 0.0000 \\
LOGAGE & 0.037386 & 0.000791 & 47.23604 & 0.0000 \\
Board Composition & -0.104737 & 0.000695 & -150.7500 & 0.0000 \\
\hline \hline
\end{tabular}

Effects Specification

Cross-section fixed (dummy variables)

\begin{tabular}{lllr}
\hline \hline R-squared & 0.903220 & Mean dependent var & 0.092930 \\
Adjusted R-squared & 0.898058 & S.D. dependent var & 0.013867 \\
S.E. of regression & 0.004428 & Akaike info criterion & -7.952311 \\
Sum squared resid & 0.059910 & Schwarz criterion & -7.642792 \\
Log likelihood & 12967.22 & Hannan-Quinn criter. & -7.841378 \\
F-statistic & 174.9736 & Durbin-Watson stat & 1.844579 \\
Prob(F-statistic) & 0.000000 & \\
\hline \hline
\end{tabular}

\subsection{Conclusion}

Corporate governance literature usually uses the agency theory and stewardship theory to explain the role of the board in reducing agency problem and promoting firm value. For instance, the stewardship theory do not see the essence of having a board dominated by non-executive directors since managers are worthy of trust. The agency theory, on the contrary perceives managers as having the incentive to pursue self-serving behaviour, and need non-executive dominated board to moderate or reduce the agency costs.

This paper contributes to resolving the controversy between agency and stewardship theories using the Nigerian data. The results however, contradict the agency theory. Specifically, the results revealed that the presence of non-executive directors in a corporate board has significant negative impact on firm performance. The finding of the result raises an important question on the best governance mechanism for resolving agency problems in the Nigerian corporate environment. 
More importantly, the result showed that non-executive directors could also pursue personal gains against effective monitoring of agents in developing economies. This situated is accentuated due to near lack of shareholder activism, institutional investors and efficient market.

\section{References}

Arellano, M. and S. Bond (1991). Some Tests of Specification in Panel Data: Monte Carlo Evidence and an Application to Employment Equations, Review of Economics and Statistics, Vol. 58 (2), 277-97.

Blundell, R. and Bond, S. (1998), Initial Conditions and Moment Restrictions in Dynamic Panel Data Models, Journal of Econometrics 87, 115 - 143

Cochran, P. L. and Wood, R. A. (1984). Corporate Social Responsibility and Financial performance, Academy of Management Journal, 27(1), 42-56

Code of Corporate Governance for Public Companies in Nigeria

Code of Corporate Governance in Banks in Nigeria Post-Consolidation 2006

Dow, G. K. (2003). Governing the Firm: Workers' Control in Theory and Practice, New York: Cambridge University Press.

Fich, E and Shivdasani, A. (2006). Are Busy Boards effective Monitors? Journal of finance, 23 (15) 1118

Forsberg, I. O (2009). Outside Directors and Managerial Monitoring, Akron Business and Economic Review; 20(23), 24-32

Ittner, C. D. and Larcker, D. F. (2003). Coming Up Short on Non-Financial Performance Measurement, Harvard Business Review, 81(11). p. 88

Jensen, M. C and Meckling, W. H (1976). Theory of the firm: Managerial behavior, agency costs, and ownership structure, Journal of Financial Economics 3, 305-60

Pfeffer, J (1972). Size and composition of corporate board of Directors: The organization and its Environment, Administrative Science Quarterly 17, 218-228

Raheja, C. (2005). Determinants of board size and composition: A theory of corporate boards, Journal of Financial and Quantitative Analysis 40, 283-306.

Sanusi L.S. (2010), The Nigerian industry: What went wrong and the way forward, Lecture delivered at the Convocation Square, Bayero University, Kano, on Friday 26 February, 2010 to mark the Annual Convocation Ceremony of the University

Yermack, D. (1996). Higher Valuation of Companies with a Small Board of Directors, Journal of Financial Economics, 40(2), 185-211.

Yermack, D. (2006). Board Members and Company Value, Financial Markets Portfolio Management, 20(1), 33-47.

Zahra, S and Pearce (1989). Board of Directors and corporate financial performance: A review and Integrative Model, Journal of Management 15, 291-334. 